\begin{tabular}{lccc} 
VERSITA & GOSPODARKA & SUROWCAMI & MINERALNYMI \\
\hline \multirow{2}{*}{ Tom 29} & 2013 & Zeszyt 4 \\
& & DOI 10.2478/gospo-2013-0039 &
\end{tabular}

\title{
Utilization of solutions obtained after magnesium removal from sphalerite concentrates with spent electrolyte derived from winning of cathode zinc
}

\begin{abstract}
Introduction
Increased content of magnesium in sphalerite concentrates is undesirable because it is transferred to the final production stage, i.e. to electrolysis of cathode zinc winning from sulfate solutions. The presence of magnesium in electrolyte causes deterioration of the technical and economical indexes, as well as affects the quality of cathode zinc. For these reasons, the magnesium content in electrolyte is strictly limited. In order to maintain an adequate level of magnesium in solution, a part of the electrolyte is removed from the electrolysis system. This solution is called spent electrolyte.

A common method of magnesium removal from sphalerite concentrates is pre-leaching with sulfuric acid solutions (Sanak-Rydlewska, Małysa 1999; Jarosiński, Fela 2009). The degree of magnesium removal and the rate of leaching are connected with the structure of the initial sphalerite concentrate, its granulation, the concentration of the sulfuric acid used, etc. (Jarosiński, Fela 2009).

This method of removing magnesium from the sphalerite concentrate is used in domestic conditions. The chemical treatment of sphalerite concentrate with sulfate acid is an effective method of removing magnesium, but requires additional operations such as flotation. The purpose of this flotation is to remove gypsum formed in the course of chemical treatment of sphalerite concentrates.
\end{abstract}

* Dr hab. inż., Instytut Gospodarki Surowcami Mineralnymi PAN, Kraków; e-mail:Ajar@min-pan.krakow.pl

** Dr., emeryt, *** Dr inż., Politechnika Krakowska. 
The paper documenting the findings of Jarosiński and Kozak (2012, patent PN) indicated that, for the removal of magnesium from sphalerite concentrates, the spent electrolyte derived from the process of zinc electrodeposition from sulfate solutions can be used.

Besides these findings, tests have been carried out on the recovery of certain components from solutions after magnesium removal (Jarosiński 2010, 2012). It should be noted that magnesium raw materials used in obtaining metallic magnesium and magnesium compounds are scarce in Poland (Radwanek-Bąk 2011; Gawlik, Mokrzycki 2011)

The subject of this paper is the winning of zinc and magnesium compounds from solutions deriving from the removal of magnesium in the process of chemical treatment of sphalerite concentrates by means of spent electrolyte. The deposits of zinc and other compounds were obtained by means of selective precipitation.

\section{Equipment and measuring methods}

Leaching conditions of sphalerite concentrates by means of spent electrolyte deriving from the zinc electrodeposition process were the same as in the preceding paper by Jarosiński

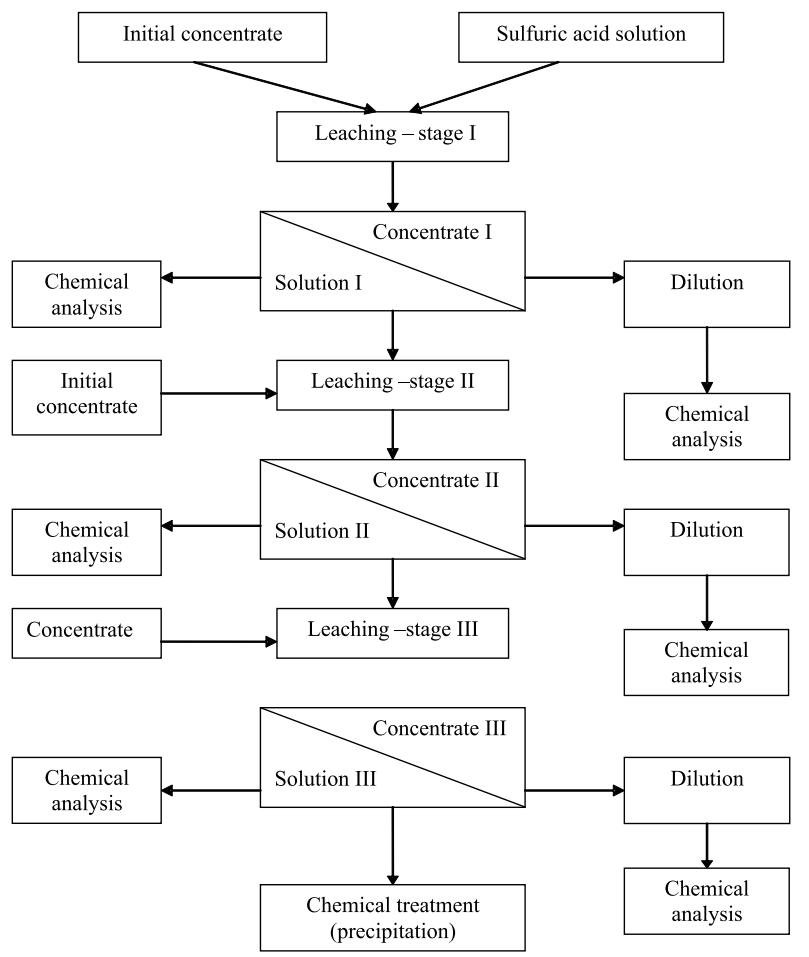

Fig. 1. The run of research procedure of magnesium removal during the process of chemical treatment (Jarosiński 2012)

Rys. 1. Schemat postępowania podczas usuwania magnezu drogą chemiczną (Jarosiński 2012) 
(2012). A schematic diagram of the course of the tests was similar to that presented in this work with the difference being that the solution after magnesium removal from concentrates was examined. This course of obtaining a solution is shown in Fig. 1. The mineral composition of the initial sphalerite was presented in previous papers, e.g. Jarosiński (2010). In order to characterize the solid products obtained by means of selective precipitation, X-ray analyses were carried out with the use of the Philips diffractometer system X Pert and infrared spectroscopy with a Scimitar series spectrophotometer. The chemical analysis of some elements was determined by means of the ICP method, using a Perkin-Elmer apparatus.

\section{Analysis of results}

\subsection{Removal of impurities from initial sphalerite concentrate}

The average chemical composition of spent solutions and initial sphalerite concentrates used for magnesium removal from sphalerite concentrate is given in Table 1.

TABLE 1

The chemical composition of spent electrolytes and sphalerite concentrates used in the analyses

TABELA 1

Skład chemiczny elektrolitów odpadowych i koncentratów sfaletytowych stosowanych w badaniach

\begin{tabular}{|c|l|c|c|c|c|c|c|c|}
\hline \hline No. & \multicolumn{1}{|c|}{ Kind of material } & $\mathrm{Zn}$ & $\mathrm{Mg}$ & $\mathrm{Ca}$ & $\mathrm{Fe}$ & $\mathrm{Na}$ & $\mathrm{Mn}$ & $\mathrm{SO}_{4}$ \\
\hline \hline 1. & Spent elektrolyte $\left[\mathrm{g} / \mathrm{dm}^{3}\right]$ & 57.5 & 11.91 & 0.45 & 1.32 & 2.63 & 4.36 & 230.4 \\
\hline 2. & Concentrate [\%] & 56.8 & 1.20 & 2.30 & 1.30 & Traces & 0.05 & \\
\hline 3. & Spent elektrolyte* $\left[\mathrm{g} / \mathrm{dm}^{3}\right]$ & 58.49 & 11.40 & 0.43 & 1.33 & 2.95 & 4.67 & 229.9 \\
\hline 4. & Concentrate [\%] & 55.56 & 1.30 & 2.49 & 1.40 & Traces & 0.03 & \\
\hline \hline
\end{tabular}

* Materials No. 1 and 2 were used in the first series of leaching tests

The extent of leaching for some components was described by the following equation:

$$
W=m_{a}-m_{i} / m_{c} 100 \%
$$

where:

$W-$ metal extent of leaching [\%],

$m_{a}-$ the metal content in solution (leaches) [g],

$m_{i}-$ amount of metal introduced with leaching agent $[\mathrm{g}]$,

$m_{c}-$ the initial metal content in the raw concentrate $[\mathrm{g}]$. 
The studies consisted of two major measuring series, namely leaching and removal of some components.

The first leaching sequence was carried out utilizing materials no 1 and 2 (Table 1). The measurement results of these series are summarized in Table 2. In this study it was found that the leaching process did not change the filtration properties of the concentrate.

The next series of measurements was carried out for materials 3 and 4 . The results are shown in Table 3 and 4. After each stage of leaching, the concentration of sulfuric acid in the solution was determined.

The collected data in Tables 3 and 4 shows that the removal of magnesium from the initial crude concentrate proceeds with a high yield. For example, after the first stage of the two-hour leaching the extent of leaching was almost $84 \%$. After the second and third stages of leaching the magnesium extent of leaching was slightly lower, with values respectively of 81.5 and 70.4. Magnesium content in the concentrate was below the maximum permissible value, i.e. $0.30 \%$. After the third stage, the content of this component was $0.40 \%$. Zinc losses were the highest after the first leaching stage at $2.6 \%$, and are acceptable from a technological point of view.

The extent of leaching in the next stages of the process resulted in values lower than 2.6. (Table 2, 3, and 4).

The data confirmed the presence of sphalerite as a primary phase, while phase loss dolomite was observed (Fig. 2). In the place of dolomite gypsum, phase appeared.

TABLE 2

Results of sphalerite concentrate leaching by means of spent electrolyte, time of leaching $1 \mathrm{~h}$ (for sample one)

TABELA 2

Wyniki ługowania koncentratu sfalerytowego za pomocą zużytego elektrolitu, czas ługowania 1 godzina

\begin{tabular}{|c|c|c|c|c|c|c|}
\hline \multirow{3}{*}{ Component } & \multicolumn{6}{|c|}{ Stage of leachnig } \\
\hline & \multicolumn{2}{|c|}{ I } & \multicolumn{2}{|c|}{ II } & \multicolumn{2}{|c|}{ III } \\
\hline & Solution & Concentrate & Solution & Concentrate & Solution & Concentrate \\
\hline $\mathrm{Zn}\left[\mathrm{g} / \mathrm{dm}^{3}\right]$ & 58.5 & - & 59.6 & - & 60.5 & - \\
\hline Content [\%] & - & 55.7 & - & 55.7 & - & 55.9 \\
\hline W [\%] & 1.90 & - & 1.87 & - & 1.60 & - \\
\hline $\operatorname{Mg}\left[\mathrm{g} / \mathrm{dm}^{3}\right]$ & 12.86 & - & 13.80 & - & 14.73 & - \\
\hline Content [\%] & - & 0.24 & - & 0.25 & - & 0.27 \\
\hline W [\%] & 79.6 & - & 78.7 & - & 77.6 & - \\
\hline $\mathrm{Ca}\left[\mathrm{g} / \mathrm{dm}^{3}\right]$ & 0.7 & - & 0.95 & - & 1.17 & - \\
\hline Content [\%] & - & 2.05 & - & 2.06 & - & 2.08 \\
\hline $\mathrm{W}[\%]$ & 10.89 & - & 10.61 & - & 9.60 & - \\
\hline $\mathrm{Fe}\left[\mathrm{g} / \mathrm{dm}^{3}\right]$ & 1.60 & - & 1.86 & - & 2.10 & - \\
\hline Content $[\%]$ & - & 1.03 & - & 1.04 & - & 1.07 \\
\hline W [\%] & 21.1 & - & 20.4 & - & 17.7 & - \\
\hline
\end{tabular}


TABLE 3

Results of sphalerite concentrate leaching by means of spent electrolyte, time of leaching $1 \mathrm{~h}$

TABELA 3

Wyniki ługowania koncentratu sfalerytowego za pomocą zużytego elektrolitu, czas ługowania 1 godzina

\begin{tabular}{|c|c|c|c|c|c|c|}
\hline \multirow{3}{*}{ Component } & \multicolumn{6}{|c|}{ Stage of leachnig } \\
\hline & \multicolumn{2}{|c|}{ I } & \multicolumn{2}{|c|}{ II } & \multicolumn{2}{|c|}{ III } \\
\hline & Solution & Concentrate & Solution & Concentrate & Solution & Concentrate \\
\hline $\mathrm{Zn}\left[\mathrm{g} / \mathrm{dm}^{3}\right]$ & 61.7 & - & 63.68 & - & 65.94 & - \\
\hline Content $[\%]$ & - & 54.5 & - & 54.56 & - & 54.66 \\
\hline $\mathrm{W}[\%]$ & 1.86 & - & 1.85 & - & 1.67 & - \\
\hline $\mathrm{Mg}\left[\mathrm{g} / \mathrm{dm}^{3}\right]$ & 14.09 & - & 16.71 & - & 19.26 & - \\
\hline Content [\%] & - & 0.25 & - & 0.28 & - & 0.29 \\
\hline $\mathrm{W}[\%]$ & 80.1 & - & 79.2 & - & 77.7 & - \\
\hline $\mathrm{Ca}\left[\mathrm{g} / \mathrm{dm}^{3}\right]$ & 1.12 & - & 1.81 & - & 2.42 & - \\
\hline Content $[\%]$ & - & 2.21 & - & 2.23 & - & 2.25 \\
\hline $\mathrm{W}[\%]$ & 11.0 & - & 10.8 & - & 9.7 & - \\
\hline $\mathrm{Fe}\left[\mathrm{g} / \mathrm{dm}^{3}\right]$ & 2.09 & - & 2.82 & - & 3.45 & - \\
\hline Content $[\%]$ & - & 1.10 & - & 1.1 & - & 1.15 \\
\hline $\mathrm{W}[\%]$ & 21.4 & - & 20.4 & - & 17.9 & - \\
\hline $\mathrm{Na}\left[\mathrm{g} / \mathrm{dm}^{3}\right]$ & 2.94 & - & 3.00 & - & 3.00 & - \\
\hline $\mathrm{Mn}\left[\mathrm{g} / \mathrm{dm}^{3}\right]$ & 4.79 & - & 4.86 & - & 4.83 & - \\
\hline $\mathrm{SO}_{4}\left[\mathrm{~g} / \mathrm{dm}^{3}\right]$ & 281.39 & - & 268.75 & - & 257.3 & - \\
\hline Content $\mathrm{H}_{2} \mathrm{SO}_{4}\left[\mathrm{~g} / \mathrm{dm}^{3}\right]$ & 117.91 & - & 87.08 & - & 58.21 & - \\
\hline
\end{tabular}

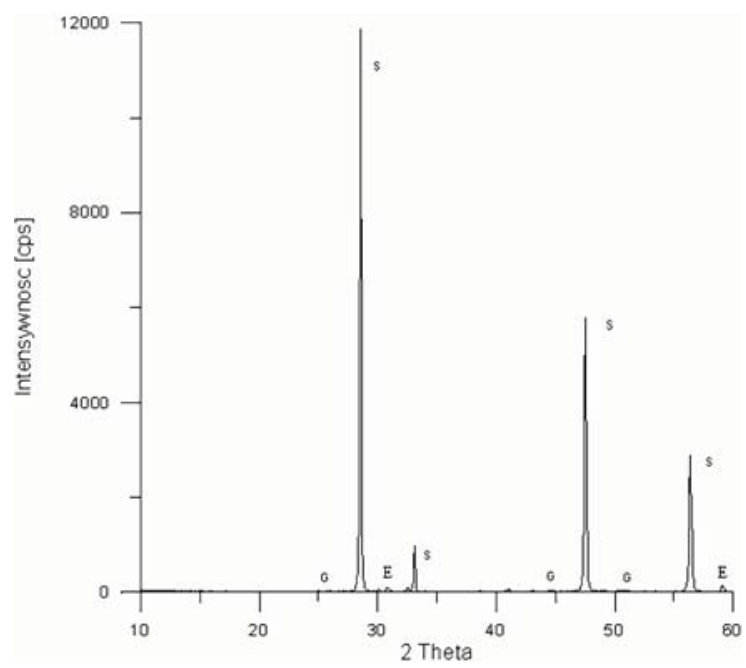

Fig. 2. X-ray diffraction pattern of the obtained concentrate after 2 hours of leaching

Rys. 2. Rentgenogram próbki koncentratu po dwugodzinnym ługowaniu kwasem siarkowym S - sfaleryt, G - galena, E - Gips 
Results of sphalerite concentrate leaching by means of spent electrolyte, time of leaching $2 \mathrm{~h}$

TABELA 4

Wyniki ługowania koncentratu sfalerytowego za pomocą zużytego elektrolitu, czas ługowania 2 godziny

\begin{tabular}{|c|c|c|c|c|c|c|}
\hline \multirow{3}{*}{ Component } & \multicolumn{6}{|c|}{ Stage of leachnig } \\
\hline & \multicolumn{2}{|c|}{ I } & \multicolumn{2}{|c|}{ II } & \multicolumn{2}{|c|}{ III } \\
\hline & Solution & Concentrate & Solution & Concentrate & Solution & Concentrate \\
\hline $\mathrm{Zn}\left[\mathrm{g} / \mathrm{dm}^{3}\right]$ & 62.05 & - & 64.60 & - & 66.96 & - \\
\hline Content $[\%]$ & - & 54.5 & - & 54.62 & - & 54.61 \\
\hline $\mathrm{W}[\%]$ & 2.6 & - & 1.80 & - & 1.70 & - \\
\hline $\operatorname{Mg}\left[\mathrm{g} / \mathrm{dm}^{3}\right]$ & 14.17 & - & 16.85 & - & 19.17 & - \\
\hline Content $[\%]$ & - & 0.25 & - & 0.25 & - & 0.40 \\
\hline $\mathrm{W}[\%]$ & 83.8 & - & 81.5 & - & 70.4 & - \\
\hline $\mathrm{Ca}\left[\mathrm{g} / \mathrm{dm}^{3}\right]$ & 1.08 & - & 1.72 & - & 2.16 & - \\
\hline Content $[\%]$ & - & 2.25 & - & 2.26 & - & 2.15 \\
\hline $\mathrm{W}[\%]$ & 10.2 & - & 9.4 & - & 7.0 & - \\
\hline $\mathrm{Fe}\left[\mathrm{g} / \mathrm{dm}^{3}\right]$ & 2.10 & - & 2.84 & - & 3.49 & - \\
\hline Content $[\%]$ & - & 1.08 & - & 1.1 & - & 1.14 \\
\hline $\mathrm{W}[\%]$ & 21.8 & - & 20.7 & - & 18.2 & - \\
\hline $\mathrm{Na}\left[\mathrm{g} / \mathrm{dm}^{3}\right]$ & 3.01 & - & 2.99 & - & 3.04 & - \\
\hline $\mathrm{Mn}\left[\mathrm{g} / \mathrm{dm}^{3}\right]$ & 4.74 & - & 4.84 & - & 4.71 & - \\
\hline $\mathrm{SO}_{4}\left[\mathrm{~g} / \mathrm{dm}^{3}\right]$ & 280.78 & - & 267.31 & - & 257.58 & - \\
\hline Content $\mathrm{H}_{2} \mathrm{SO}_{4}\left[\mathrm{~g} / \mathrm{dm}^{3}\right]$ & 115.73 & - & 81.52 & - & 55.98 & - \\
\hline
\end{tabular}

\section{Preparation of products from the leaching solution}

Chemical methods of purification and separation of the components from the solution are limited to the selective precipitation of selected components of the solution. In general, the products in the form of oxides, hydroxides, or salts from the solutions are separated. In this series of measurements, solutions after the third stage of leaching were used. The course of the research procedure is shown in Fig. 3.

The main purpose of this series of tests was the selective separation of zinc and magnesium from the solution of zinc and magnesium in hydroxide form. The $\mathrm{pH}$ values at which precipitation begins and ends were calculated according to the data given in the work (Jarosiński 2012). For example, pH values calculated for $\mathrm{Zn}(\mathrm{OH})$ were: initial 4.42 and final 6.62; while the zinc concentrations amounted to $1.024 \mathrm{M} / \mathrm{dm}^{3}$. For magnesium, these values were respectively 9.44 and 10.97 , with magnesium concentrate amounting 
to $0.785 \mathrm{M} / \mathrm{dm}^{3}$. Neutralization of the solution by means of a $10 \%$ solution of sulfuric acid was the last stage of the precipitation of products.

The chemical composition of the solid phase after neutralization of the solution deriving from the third stage of leaching is presented in Table 5. The mineralogical characteristics of

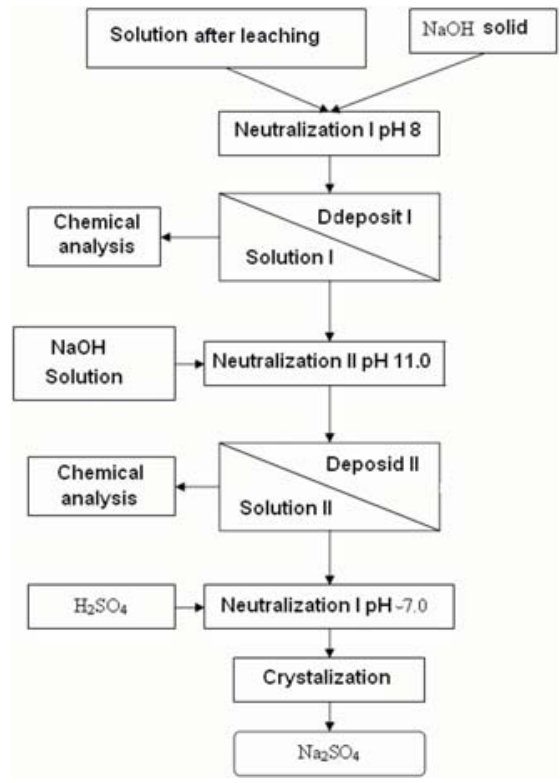

Fig. 3. The run of cleaning and separation of some components from solution after stage III of leaching

Rys. 3. Sposób oczyszczania i wydzielania składników z roztworu po III etapie ługowania

TABLE 5

Neutralization of solution after one hour

TABELA 5

Neutralizacja roztworu z III ługowania po jednej godzinie

\begin{tabular}{|c|c|c|c|c|c|}
\hline \multirow{3}{*}{ Component. } & \multicolumn{4}{|c|}{ Concentrate } & \multirow{3}{*}{$\begin{array}{c}\text { Solid phase } \\
\text { composition after } \\
\text { neutralization by } \\
\mathrm{H}_{2} \mathrm{SO}_{4}, \mathrm{pH}=7\end{array}$} \\
\hline & \multicolumn{2}{|c|}{ pH about 8.4} & \multicolumn{2}{|c|}{$\mathrm{pH}$ about 11.1} & \\
\hline & Solid phase & {$[\%]$} & Solid phase & {$[\%]$} & \\
\hline $\mathrm{Zn}$ & $\mathrm{Zn}_{4}(\mathrm{OH})_{6} \mathrm{SO}_{4} \cdot 4 \mathrm{H}_{2} \mathrm{O}$ & 88.51 & Minute quantites & - & Minute quantites \\
\hline $\mathrm{Mg}$ & $\mathrm{Mg}(\mathrm{OH})_{2}$ & 0.67 & $\mathrm{Mg}(\mathrm{OH})_{2}$ & 93.12 & 0.03 \\
\hline $\mathrm{Ca}$ & $\mathrm{Ca}(\mathrm{OH})_{2}$ & 0.18 & $\mathrm{Ca}(\mathrm{OH})_{2}$ & 0.43 & 0.09 \\
\hline $\mathrm{Mn}$ & $\mathrm{Mn}_{3} \mathrm{O}_{4}$ & 3.26 & $\mathrm{Mn}_{3} \mathrm{O}_{4}$ & 2.51 & Minute quantites \\
\hline $\mathrm{Fe}$ & $\mathrm{FrO}(\mathrm{OH}$ & 4.81 & Minute quantites & - & Minute quantites \\
\hline $\mathrm{Na}$ & Minute quantites & - & Minute quantites & - & 96.95 \\
\hline$\Sigma$ & 97.60 & 97.43 & 96.96 & 96.06 & 97.04 \\
\hline
\end{tabular}


the obtained products were determined by X-ray powder diffraction, presented in Fig. 4 and 5. The data in Fig. 4 indicates that the main phase of the product obtained at $\mathrm{pH} 8.4$ was $\mathrm{Zn}_{4} \mathrm{SO}_{4}(\mathrm{OH})_{6} 4 \mathrm{H}_{2} \mathrm{O}$. The analysis of the electrochemical diagram $\mathrm{E}=\mathrm{f}(\mathrm{pH})$ for system $\mathrm{Zn}-\mathrm{H}_{2} \mathrm{SO}_{4}-\mathrm{H}_{2} \mathrm{O}$ confirms that in the considered range of $\mathrm{pH}$, basic zinc sulfate forms.

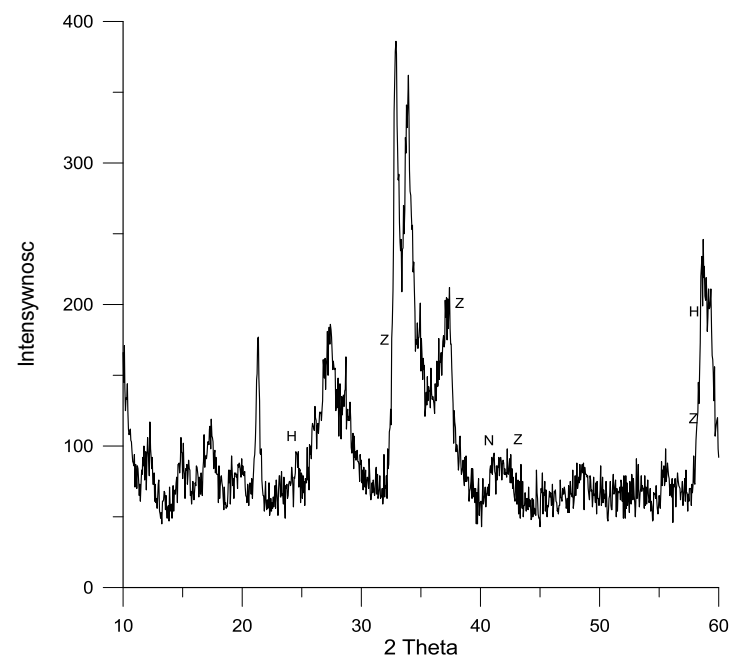

Fig. 4. X-ray diffraction pattern of the product obtained after neutralization of solution $\mathrm{pH}=8.3$ (solution after stage III of leaching)

Rys. 4. Dyfraktogram produktu otrzymanego po neutralizacji roztworu do $\mathrm{pH}=8,3$ (z roztworu po III etapie ługowania) $\mathrm{Z}-\mathrm{Zn}_{4} \mathrm{SO}_{4}(\mathrm{OH})_{6} 4 \mathrm{H}_{2} \mathrm{O}, \mathrm{N}$ - tlenek manganu $\left(\mathrm{Mn}_{3} \mathrm{O}_{4}\right), \mathrm{H}-$ goetyt

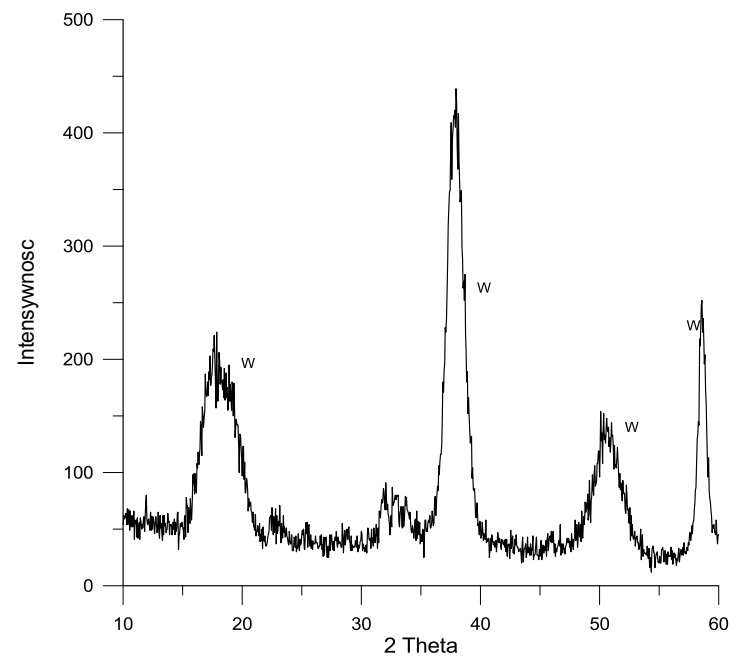

Fig.5. X-ray diffraction pattern of magnesium hydroxide obtained after stage II of neutralization $\mathrm{W}$ - magnesium hydroxide

Rys. 5. Dyfraktogram otrzymanego wodorotlenku magnezu po II etapie neutralizacji W - wodorotlenek magnezu 
The compound is contaminated with iron in a goethite form and manganese oxide. The presence of magnesium hydroxide in the sample deriving from the neutralization of the solution by $\mathrm{pH} 11.1$ is presented in Fig. 5.

IR spectra of the final product show the presence of sodium sulfate $-\mathrm{Na}_{2} \mathrm{SO}_{4} \cdot 10 \mathrm{H}_{2} \mathrm{O}$ (Fig. 6).

TABLE 6

Neutralization of solution after 2 hours

TABELA 6

Neutralizacja roztworu z III ługowania po dwóch godzinach

\begin{tabular}{|c|c|c|c|c|c|}
\hline \multirow{3}{*}{ Component. } & \multicolumn{4}{|c|}{ Concentrate } & \multirow{3}{*}{$\begin{array}{c}\text { Solid phase } \\
\text { composition afte } \\
\text { neutralization by } \\
\mathrm{H}_{2} \mathrm{SO}_{4}, \mathrm{pH}=7 \\
\end{array}$} \\
\hline & \multicolumn{2}{|c|}{$\mathrm{pH}$ about 8.3} & \multicolumn{2}{|c|}{$\mathrm{pH}$ about 11.2} & \\
\hline & Solid phase & {$[\%]$} & Solid phase & {$[\%]$} & \\
\hline $\mathrm{Zn}$ & $\mathrm{Zn}_{4}(\mathrm{OH})_{6} \mathrm{SO}_{4} \cdot 4 \mathrm{H}_{2} \mathrm{O}$ & 89.62 & Minute quantites & 93.91 & Minute quantites \\
\hline $\mathrm{Mg}$ & $\mathrm{Mg}(\mathrm{OH})_{2}$ & 0.72 & $\mathrm{Mg}(\mathrm{OH})_{2}$ & 0.42 & 0.03 \\
\hline $\mathrm{Ca}$ & $\mathrm{Ca}(\mathrm{OH})_{2}$ & 0.19 & $\mathrm{Ca}(\mathrm{OH})_{2}$ & 2.63 & 0.09 \\
\hline Mn & $\mathrm{Mn}_{3} \mathrm{O}_{4}$ & 3.16 & $\mathrm{Mn}_{3} \mathrm{O}_{4}$ & - & Minute quantites \\
\hline $\mathrm{Fe}$ & $\mathrm{FrO}(\mathrm{OH}$ & 4.91 & Minute quantites & - & Minute quantites \\
\hline \multirow[t]{2}{*}{$\mathrm{Na}$} & Minute quantites & - & Minute quantites & - & 95.89 \\
\hline & 97.43 & 97.60 & 96.06 & 96.96 & 95.93 \\
\hline
\end{tabular}

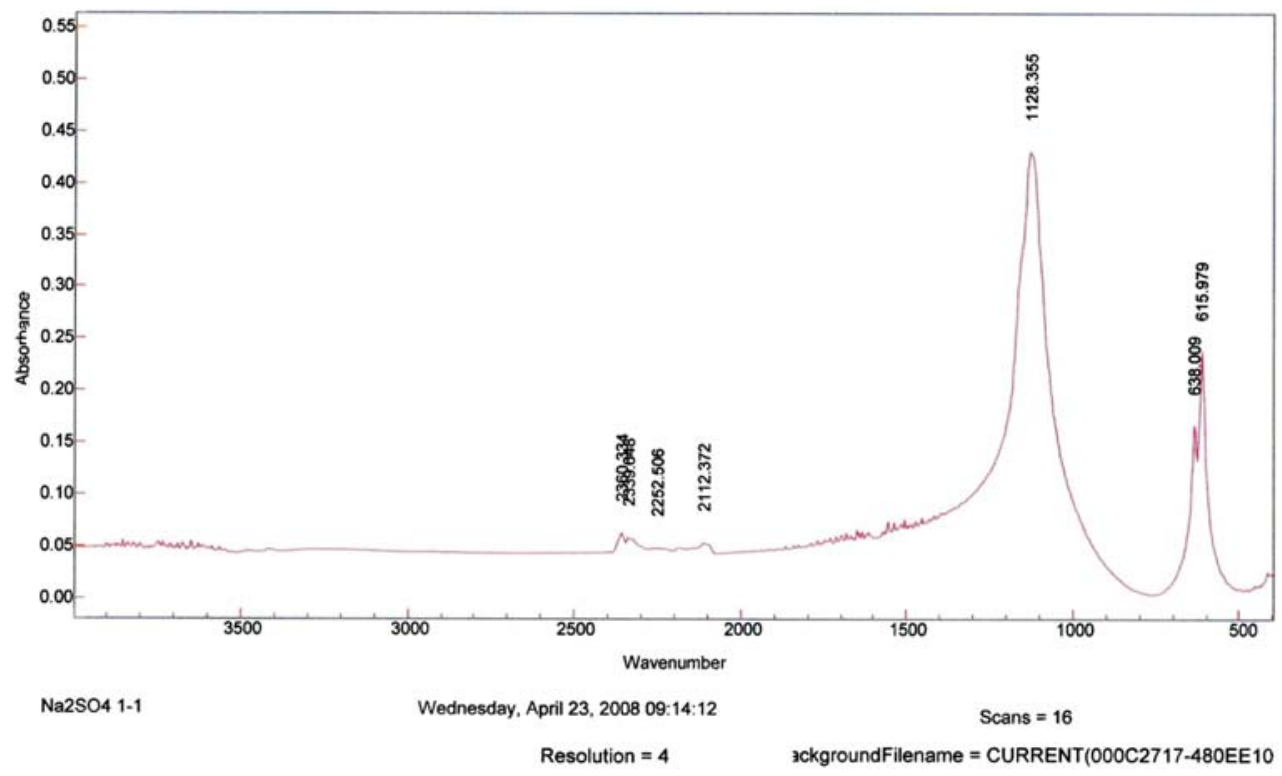

Fig. 6. IR spectra of obtained product by means of crystallization $\mathrm{pH}=7$

Rys. 6. Widmo IR produktu otrzymanego na drodze krystalizacji $\mathrm{pH}=7$ 


\section{Remarks}

The following conclusions can be drawn from this study. The data confirmed that the leaching process with spent electrolyte is an effective method for the removal of magnesium and other impurities. The procedure for purification and separation of components from solution is accurate. The resulting products can be utilized in various technological processes; for example, in the production of magnesium compounds, recycling of zinc product, winning of zinc, etc.

From every ton of spent electrolyte and 0.2 tons of initial sphalerite concentrate, on average $107 \mathrm{~kg}$ of $\mathrm{Zn}_{4} \mathrm{SO}_{4}(\mathrm{OH})_{6} \cdot 4 \mathrm{H}_{2} \mathrm{O}, 37 \mathrm{~kg} \mathrm{Mg}(\mathrm{OH})_{2}$, 4-5 $\mathrm{kg} \mathrm{FeOOH}$, and $17 \mathrm{~kg}$ $\mathrm{Na}_{2} \mathrm{SO}_{4} \cdot 10 \mathrm{H}_{2} \mathrm{O}$ can be recovered.

\section{REFERENCES}

Gawlik L., Mokrzycki E., 2011 - Mineral Raw materials of Poland - Resource aspect, Sustainable production and consumption of mineral resources. Wyd. IGSMiE PAN, Kraków, s. 13-39.

Jarosiński A., Fela K., 2009 - The optimization of low-magnesium zinc concentrate production process. Polish Journal of Chemical Technology t . 1, s. 20-23.

Jarosiński et al. 2010 - Jarosińsk i A., Kozak A., Że la zn y S., 2010 - Recovery of some components from solutions after magnesium removal with zinc concentrate. 14th Conference on Environmental and Mineral Processing, VSB-TU Ostrava. Part I. s. 273-276.

Jarosiński et al. 2012 - Jarosiński A., Kozak A., Żelazny S., Radomski P., 2012 - Removal of magnesium from sphalerite concentrates by means of spent electrolyte deriving from the process of cathode zinc extraction. Mineral Resources Management (Gospodarka Surowcami Mineralnymi) t. 28, z. 3, s. 43-53.

Jarosiński A., 2012 - Innowacyjne i proekologiczne metody przeróbki materiałów cynkonośnych. Wyd. IGSMiE PAN, Kraków.

Patent PN-213 175, 2012.

R a d w a n e k-B ąk B., 2011 - Zasoby kopalin Polski w aspekcie oceny surowców krytycznych Unii Europejskiej. Mineral Resources Management (Gospodarka Surowcami Mineralnymi) t. 27, z. 1, s. 5-19.

Sanak-Rydlewska S., Małysa E., 1996 - Purification of zinc blende concentrate by chemical flotation treatment to remove magnesium. Archive of Metallurgy t. 41, s. 435-440.

ZAGOSPODAROWANIE ROZTWORÓW PO USUWANIU MAGNEZU Z KONCENTRATÓW SFALERYTOWYCH ELEKTROLITEM ODPADOWYM Z PROCESU OTRZYMYWANIA CYNKU KATODOWEGO

\section{Słowa kluczowe}

Wysoko jakościowy koncentrat sfalerytowy, usuwanie magnezu, oczyszczanie roztworów, odzysk wybranych składników

\section{Streszczenie}

Krajowe złoża rud cynku i ołowiu występują w skałach dolomitowych co powoduje, że pozyskiwane koncentraty sfalerytowe zawierają domieszki dolomitu. Koncentraty te powinny cechować się wysoką zawartością cynku i niskim poziomem zanieczyszczeń, takich jak magnez, arsen, żelazo i inne. Krajowy proces wytwarzania 
cynku katodowego z powyższego surowca obejmuje: prażenie koncentratu sfalerytowego (w celu otrzymania cynku w postaci tlenkowej), ługowanie tego koncentratu kwasem siarkowym, oczyszczanie otrzymanego roztworu siarczanu (VI) cynku i elektroosadzanie cynku jako ostatni etap procesu. Podczas obróbki chemicznej koncentratu tlenkowego kwasem siarkowym magnez przechodzi prawie całkowicie do roztworu siarczanu (VI) cynku. Wysokie stężenie magnezu w tym roztworze jest niepożądane i przyczynia się do pogorszenia jakości cynku katodowego, jak również do pogorszenia wskaźników techniczno-ekonomicznych procesu elektrolizy. Postulowana zawartość magnezu w roztworze wynosi poniżej 0,3\% MgO i dlatego $\mathrm{MgO}$ powinno być usuwane przed elektrolizą cynku. Jedną z metod usuwania magnezu jest obniżenie jego zawartości w koncentracie sfalerytowym na drodze ługowania wstępnego, stosując kwas siarkowy jako czynnik ługujący .

Celem tych badań był odzysk niektórych składników z roztworów po usunięciu magnezu z koncentratu sfalerytowego poprzez jego ługowanie. Czynnikiem ługującym był zużyty elektrolit pochodzący z procesu elektroosadzania cynku. Badania obejmowały dwie zasadnicze serie pomiarowe: ługowanie wyjściowego koncentratu sfalerytowego zużytym elektrolitem z elektrolizy cynku i odzysk niektórych składników z otrzymanych roztworów. Po pierwszym dwugodzinnym ługowaniu stopień wyługowania wynosił około 84\%. Po drugim i trzecim etapie stopień wyługowania był nieco niższy i wynosił odpowiednio 81,5\% i 70,4\%. Zawartość magnezu w koncentracie sfalerytowym była poniżej maksymalnej dopuszczalnej wartości, to jest 0,3\% MgO. Po trzecim etapie ługowania zawartość tego składnika wynosiła $0,4 \% \mathrm{MgO}$. Straty cynku były najwyższe po pierwszym etapie ługowania i osiągnęły wartość $2,6 \%$ co jest do przyjęcia z technologicznego punktu widzenia. Otrzymane wyniki potwierdziły, że proces ługowania za pomocą zużytego elektrolitu jest efektywnym sposobem usuwania magnezu i innych zanieczyszczeń z koncentratu cynku. Opisana procedura oczyszczania i wydzielania składników z roztworów jest efektywną metodą odzysku wybranych składników. Otrzymane produkty mogą być zagospodarowane w różnych procesach technologicznych, na przykład do produkcji związków magnezu czy produkty cynkonośne do ponownego ich wykorzystania w procesie wytwarzania cynku katodowego.

UTILIZATION OF SOLUTIONS OBTAINED AFTER MAGNESIUM REMOVAL FROM SPHALERITE CONCENTRATES WITH SPENT ELECTROLYTE DERIVED FROM WINNING OF CATHODE ZINC

$$
\text { Key words }
$$

High quality sphalerite concentrates, magnesium removal, purification of solutions and recovery of some components

\section{Abstract}

As domestic zinc and lead deposits occur in dolomite rocks, the sphalerite concentrates obtained from these ores contain an admixture of dolomite. These concentrates should be characterized by a high content of zinc and low levels of impurities such as magnesium, arsenic, iron, and others. The domestic process of cathode zinc winning from this raw material consists of roasting of sphalerite concentrates (in order to obtain zinc in the oxide form), leaching of the oxide concentrate with sulfuric acid, purification of the zinc sulfate obtained, and a final stage-zinc electrodeposition. During chemical treatment of the oxide concentrate with sulfuric acid, magnesium is added to the solution of zinc sulfate. A high magnesium concentration in the solution is undesirable, and causes deterioration of zinc cathode quality, and technical as well as economical indexes of the process. The required content of magnesium in a solution amounts to less than $0.3 \% \mathrm{MgO}$; therefore, $\mathrm{MgO}$ should be removed before the electrodeposition of zinc. One of the methods of magnesium removal is decreasing its content in a sphalerite concentrate by means of pre-leaching, using sulfuric acid as a leaching agent.

The aim of this study was the recovery of certain components from solutions after magnesium removal with zinc concentrates by means of pre-leaching. Spent electrolyte deriving from the zinc electrodeposition process was used as the pre-leaching agent. The study consisted of two major measuring series, namely leaching of raw sphalerite concentrate with spent electrolyte and removal of components from the solutions after pre-leaching. Leaching was carried out in three stages. After the first stage of the two-hour leaching, the extent of magnesium 
leaching was almost $84 \%$. After the second and third stages of the leaching steps, magnesium content was slightly lower respectively 81.5 and $70.4 \%$. Magnesium content in the concentrate was below the maximum permissible value, i.e. $0.30 \%$. After the third stage, the content of this component was $0.40 \%$. Zinc losses were highest after the first leaching stage at $2.6 \%$, and were acceptable from a technological point of view. The results confirmed that the pre-leaching process with spent electrolyte is an effective method for the removal of magnesium and other impurities from zinc concentrate. The described procedure for purification and separation of components from a solution is an effective method of recovering some components. The resulting products can be utilized in various technological processes; for example, for the production of magnesium compounds, recycling of zinc product, winning of zinc, etc. 